\title{
THE CALORIGENETIC ACTION OF THYROXIN AT DIFFER- ENT LEVELS OF BASAL METABOLISM IN MYXEDEMA
}

By WILLARD OWEN THOMPSON, ${ }^{1}$ PHEBE K. THOMPSON, ${ }^{2}$ ALLEN G.

(From the Thyroid Clinic and the Metabolism Laboratory of the Massachusetts General Hospital)

(Received for publication March 22, 1929)

INTRODUCTION

In the course of a study of the change in plasma volume accompanying treatment with desiccated thyroid in myxedema (1), it was noted that after the basal metabolic rate had been restored to normal, further increases in thyroid dosage up to four times the maintenance requirement produced proportionately much smaller increases in basal metabolism than did the maintenance dose. The effect at a normal level, in fact, appeared to be of about the same magnitude as that produced by giving thyroid to a normal individual.

It seemed desirable to confirm these observations, using thyroxin intravenously instead of desiccated thyroid by mouth, in order to eliminate the possibility of non-absorption of the latter from the gastro-intestinal tract.

\section{METHOD}

Accordingly, two patients with untreated typical myxedema were each given $10 \mathrm{mgm}$. of thyroxin intravenously, and the influence on heat production and on clinical symptoms were compared with those following the same dose given to each patient at a later period when the basal metabolism was maintained at a normal level by desiccated thyroid (figs. 1 to 6).

Both patients were kept in the hospital on routine diet throughout the "thyroxin curve" periods, with the exception of the second patient

\footnotetext{
${ }^{1}$ Fellow of the National Research Council. Research Fellow in Medicine, Harvard Medical School and Massachusetts General Hospital.

${ }^{2}$ Research Fellow in Medicine, Massachusetts General Hospital.
} 
who was not in the hospital during the time covered by the latter two-thirds of the first curve.

It is very important to keep the patient for a long time on a given dose of desiccated thyroid before drawing the conclusion that a metabolic level is established on that dose. The first patient was kept for four months on three grains of desiccated thyroid daily before the second injection of thyroxin. The second patient was kept for nearly two months on three grains, and then for four months on one and one-half grains of dessicated thyroid daily before the second injection of thyroxin; and on three grains daily for nine months before the third injection. Moreover, after a level had been established on these doses at home, a change occurred after return to the hospital: the metabolism determinations were usually lower, evidently due to the elimination of a rather long journey to the hospital before each test.

In order to keep conditions constant throughout the experiment, the daily doses of desiccated thyroid were continued following the second and third injections of thyroxin.

Basal metabolic rates were determined with the Roth-Benedict apparatus, using Aub-DuBois stndards.

We used Squibb's thyroxin and Armour's desiccated thyroid.

DATA

The course of the basal metabolic rate, of the pulse and of the weight in each instance, is depicted in figures 1 and 2 . The effect of each injection on the basal metabolism is shown in detail in figures 3 and 4 . The temperature reactions after each injection are shown in figures 5 and 6.

The general clinical course of the toxic effects of an injection of thyroxin has been described by Boothby, Sandiford, Sandiford and Slosse (2), but detailed descriptions of the onset and duration of both toxic and beneficial effects in their relation to metabolism, have not been reported. For this reason, the clinical histories of these two patients are given in detail.

Case 1 (figs. 1, 3 and 5). Lab. No. 4671. Mrs. E. G. Age 48. A case of untreated typical myxedema. On entering the hospital May 7th, 1927, her face was puffy, and she had swelling of the hands and legs which felt numb and clumsy. She had gained 60 pounds in the last four years. Her tongue was thick and her 
$\begin{array}{llll}95 & 5 & 3 & 3\end{array}$

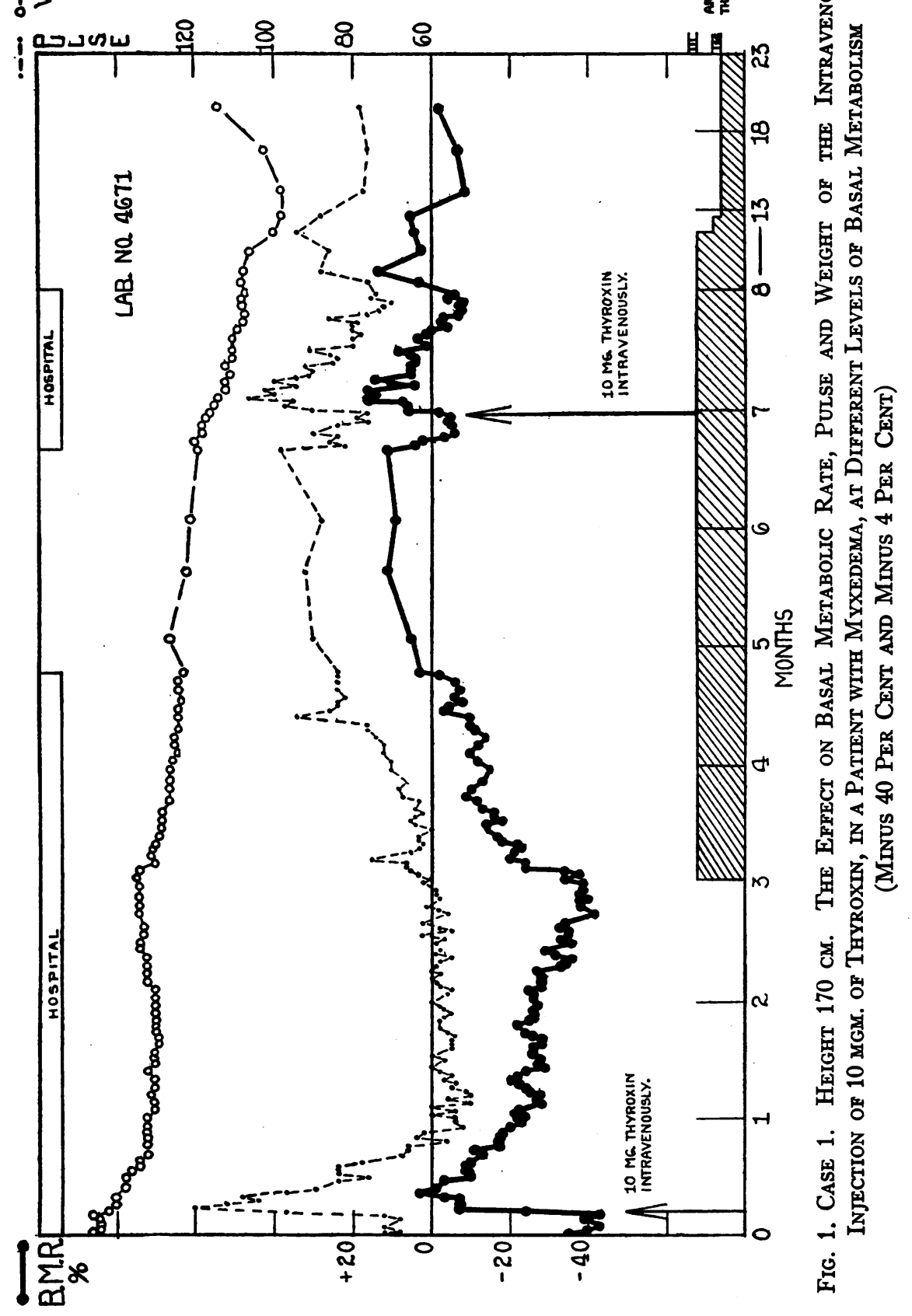




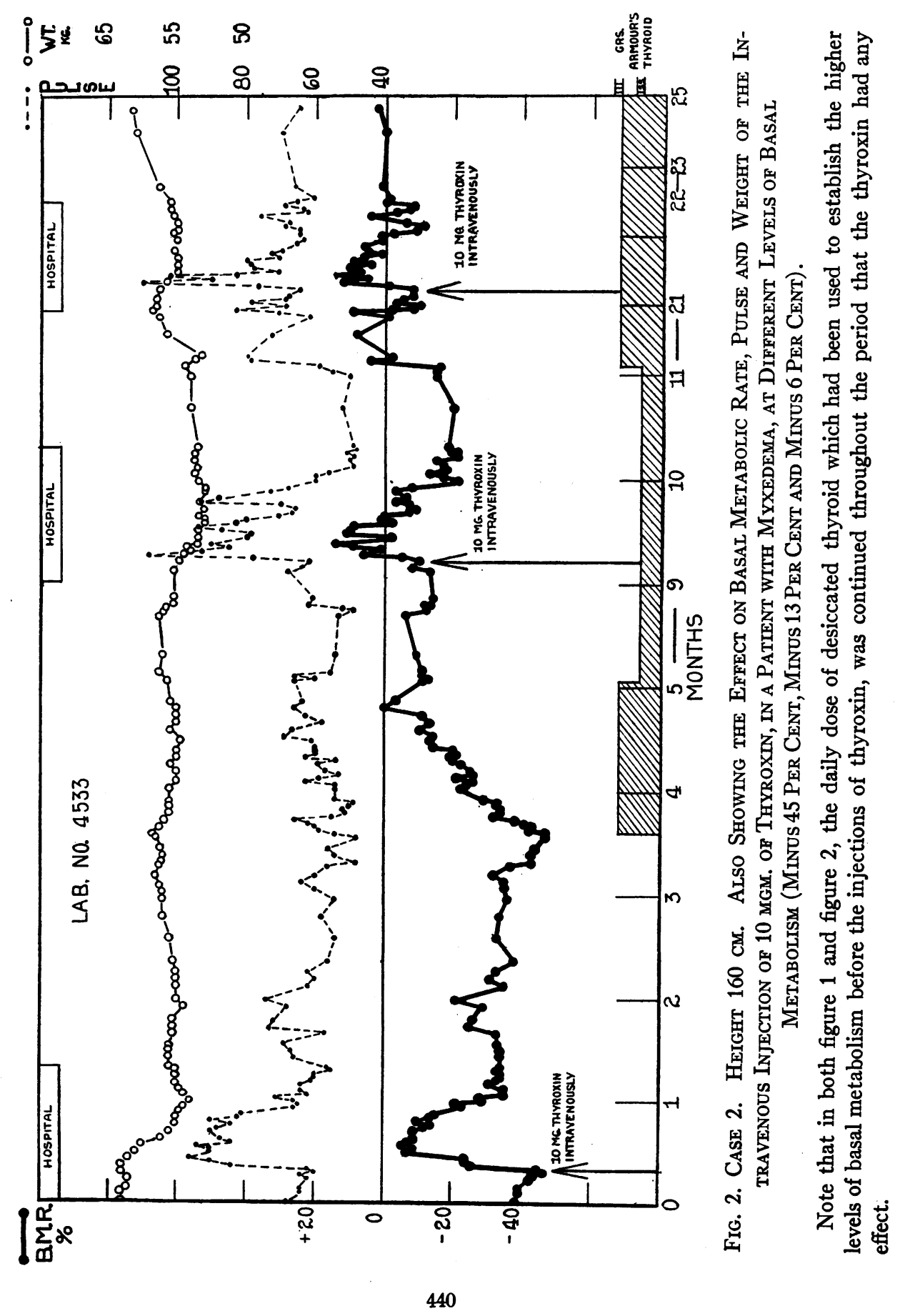


hair very dry and brittle. Her skin was dry and scaly and showed marked pigmentation on the face and arms. Her voice was hoarse and her speech extremely slow and deliberate. She felt sleepy, weak and cold all the time, and had some dyspnea and palpitation on exertion. She never perspired. Her appetite was poor and she was constipated. She was markedly slowed mentally, her memory was very poor, and she was somewhat deaf. Her catamenia had been absent for six years. Her basal metabolic rate was minus 40 per cent.

On May 14th at 3 p.m. she was given 10 milligrams of thyroxin intravenously. At 6 p.m. her skin felt warmer and her pulse had risen slightly. She had some palpitation during the night. Next morning she appeared brighter and talked faster. The edema of her eyelids had noticeably diminished. There was slight pain on moderate pressure of muscles of the right neck, upper arm and the lower half of both legs. The following day she had marked palpitation and felt as if she were burning up. She was nauseated and vomited three times. She had a slight watery nasal discharge. On the 17th the edema of Her eyelids was practically all gone. Her mouth and lips were parched. She was thirsty and was passing more urine than usual. There was no increase in muscle soreness. The next day she noticed that she felt less drowsy and that the skin on her face was softer, although it was still rough and dry on her hands. Her tongue felt as though it had "more room" in her mouth. On the 19th the muscle soreness had increased somewhat. On the 20th it was noted that the skin of her hands was definitely smoother and softer. Her heart was much quieter. Her facial expression had completely changed, due to the disappearance of edema. Her basal metabolism had reached its highest level of plus 3 per cent. By the 25th her skin was peeling all over her body. She felt brighter and stronger and moved about much more quickly. The muscle soreness was not as marked. The pigmentation of her skin was beginning to fade. Her hair was starting to fall out. By the 30th the desquamation of her skin was very marked, particularly on her legs. Although still edematous at the ankles, her legs felt much less heavy and numb. She did not mind the cold and her appetite was improving. Her voice was much less hoarse and she talked much more quickly than on entry. June 3rd the peeling of the skin was less marked and her hands did not feel as hot. Her ankles were still swollen slightly, but there was no edema of the face. On the 11th she stated that her hearing was better and that she could think more quickly than before the injection of thyroxin. She could also move her fingers and toes more easily. June 15th she was still improving, although her basal metabolism had fallen to minus 28 per cent. June 18th edema of the eyelids began to recur and she began to feel as if she would enjoy a nap after lunch. She had had no ankle swelling for about a week. July 2nd she was still feeling well and was able to walk around the hospital yard six times without resting-the first time she had accomplished such a feat. July 4 th her voice was slightly hoarse and she talked a trifle more slowly. The pigmentation of her skin had faded still more. July 12 th the skin had stopped peeling on her face but was still peeling markedly 
on her palms. She found it harder to keep balanced when walking. July 20th she felt more drowsy. July 29th her lower eyelids were markedly swollen on arising. The thick heavy skin on the soles of her feet had begun to peel. Her basal metabolism was minus 33 per cent. August 8 th she had some numbness of the fingers of her left hand. Her skin was slightly dry and it had just finished peeling on her hands. Her hair was not falling out. She was somewhat slowed up and her walking was a little unsteady. Her tongue was gradually becoming thick again. Marked edema of the eyelids was present on arising, but there was no noticeable increase in edema elsewhere. She was not cold and said that she felt much stronger and brighter than when she entered the hospital. Her basal metabolism had reached its pre-injection level of minus 40 per cent.

On August 9th she was started on 3 grains of Armour's desiccated thyroid daily. Within two days she felt brighter and less sleepy. By August 16th the puffiness of her eyelids had diminished considerably and by August 29th it was gone. She felt tired however. By September 3rd the skin on her feet had stopped peeling. She had slight muscle and joint pains. Her hair was falling out a little but new hair was growing in. October 1st she was discharged from the hospital with a normal basal metabolism. Her skin was smooth except for some peeling on her arms and hands. There was no edema of her eyelids. Her feet felt more supple and she was stronger and brighter than one month previously. The pigmentation on her arms and face had faded markedly. While home, she became more nervous, tired easily and appeared a little "washed out." October 23rd she had her first normal catamenia for seven years. She was readmitted to the hospital November 29th. In a few days she felt more rested. Her level of basal metabolism was minus 4 per cent.

She was given $10 \mathrm{mgm}$. of thyroxin intravenously at 12 p.m. December 8th. Desiccated thyroid (3 grains daily) was continued. December 9th she noted no change except that she felt warmer, her heart pounded somewhat and the muscles of her left arm were slightly tender. That night she had a slight feeling of suffocation and had "catching pains" in her left axilla for about 15 minutes. December 10th she was a little nervous and "shaky." By the 11th she was still feeling warmer and perspiring more. Her pulse became rapid only on exertion. "She had anorexia and slight nausea but no vomiting. On the 12 th she was very thirsty and was unsteady on her feet. December 13th, when in bed, she felt well; when walking about she got "shaky." She had attacks of marked perspiration and her mouth felt dry and parched. December 14th she was tremulous, had intermittent muscle pains, and felt hot and fidgety. On the 15th she felt much better. Her appetite was improving. December 16th, although still somewhat fidgety, her muscle pains had disappeared. She noticed a marked increase in salivation since receiving thyroxin. She had practically no palpitation. On the 18th she still felt unusually warm. The pigmentation of her skin had almost completely faded. December 20 th she had no complaints. She felt better than she did on entry in that she was more rested. Her nervousness had practically disappeared. On the 29 th she was clinically the same. Her skin was still 
slightly more warm and moist than normal, although this had decreased noticeably within the last week. Her hair had begun to fall out about one week previously. By January 1st, 1928 her basal metabolism had returned to its pre-injection level. On the 7th she was discharged from the hospital, still taking 3 grains of desiccated thyroid daily. After she went home, as she was tiring easily and was nervous and restless at night, perspired easily and had some precordial pain and palpitation, her dose of thryoid was reduced to 2 grains daily on April 28th and to $1 \frac{1}{2}$ grains daily on May 25th. On this smaller dose she gradually became stronger. When last seen December 21st, 1928, she was well, had no palpitation, was not nervous, did not tire easily and weighed a little more than when taking 3 grains of thyroid daily. There were no signs or symptoms of myxedema. Her basal metabolism was minus 2 per cent.

Case 2 (figs. 2, 4 and 6). Lab. No. 4533. Mrs. M. B. Age 30. On entering the hospital February 19th, 1927, she was a classical case of untreated myxedema. She had been steadily gaining weight and had had no catamenia for five years. Her tongue, face, hands, abdomen and legs were swollen. Her hair was coarse and dry. Her skin was very dry and scaling and she never perspired. Her speech was slow. She was always cold and drowsy. Her appetite was poor, she was nauseated in the mornings and was very constipated. Her mental processes had become very slow and her memory poor. She was ataxic and had frequent headaches. The level of her basal metabolism was minus 45 per cent.

On March 3rd, at 3 p.m. she was given $10 \mathrm{mgm}$. of thyroxin intravenously. At midnight she passed an unusually large amount of urine. All the next day she had a severe headache and marked nausea and anorexia, with increased thirst. She felt warm and objectively her face felt very hot. There was a noticeable diminution in the edema of her eyelids. She had slight pains all over her body and by evening her arm and leg muscles were sore on moderate pressure. March 5th her headache was less severe. She felt very hot-her temperature was $104^{\circ} \mathrm{F}$. In the afternoon all her tissues all over her body were extremely sore. She sweated profusely all night. Next day her muscle soreness was much less, although still marked in the leg muscles. She was nervous and tremulous. The edema of her face had markedly diminished. March 10th her basal metabolism had reached its highest level of minus 6 per cent. For the first time in several days she was able to eat a moderate amount. She talked faster and louder and felt much brighter. She was still thirsty and passing an increased amount of urine. On the 12th the swelling had disappeared from her face and none was noticeable elsewhere in the body. She had no headache. She shook violently on trying to stand up. She had had no nausea and vomiting for two days and her muscle soreness had subsided. She looked much brighter. The skin on her hands was more moist and smooth and the skin on her face and feet had just begun to peel. March 14th she felt much improved and could walk better than for a week. Her appetite was fair. By the 20th she was "feeling good," but she could not eat. On the 23rd her skin was still dry on her trunk, although definitely softer on her 
face, where it had practically stopped peeling. The skin on her arms had begun to peel, and her hair had started to fall out. She was still very thirsty. On the 25th her thirst and polyuria began to decrease. March 30th her appetite was normal. The skin on her hands was softer and smoother. She was still constipated. Several small boils had developed on her chest. She was able to walk without difficulty, and she was discharged from the hospital on April 3rd. She was followed at two to three-day intervals subsequently. In a few days time she contracted a cold, but her temperature was never above $97.8^{\circ} \mathrm{F}$. By April 20th she had become sensitive to cold, her appetite was poor, she was nauseated, felt weaker and had some ataxia. By April 26th she had improved in strength and her appetite was better. On the 28th she went shopping by herself for the first time in four years. Her hair had stopped falling out. By May 10th however, she was having vomiting spells and anorexia. Her abdomen had become somewhat distended again, and she was feeling tired, sleepy and cold. The skin on her face and hands was still smooth. By the 21st slight edema of her eyelids was noticeable. She said she felt just as strong as one month previously. She was able to walk down town alone - a distance of about a mile. On the 23 rd she developed an infection of the right finger, which gradually cleared up. June 2nd she developed erysipelas, which cleared up in a few days time. About June 4th her basal metabolism was at its pre-injection level of minus 45 per cent. June 7 th her eyelids were moderately puffy. She was weaker than one month previously, but could walk fairly well. Her skin was slightly dry all over her body: it was still peeling on the soles of her feet. She felt sleepy and nauseated and minded the cold, but none of her symptoms were as marked as when she entered the hospital.

She was started on 3 grains of Armour's desiccated thyroid daily on June 7 th. June 9th she felt brighter and less sleepy. Although it was an extremely hot day, the temperature was "just right" for her. On the 10th her eyelids were less puffy and she felt stronger. June 12th the puffiness was practically gone. She had nausea and vomiting and felt "shaky." She had no increased thirst. June 15th she had pain on pressure of her thighs and legs. On the 16th she began to get thirsty and to pass more urine. She was more nervous. On the 25 th her nausea disappeared. By June 29th, when her basal metabolism was minus 19 per cent, her signs and symptoms of myxedema had cleared up and she was feeling well in general. About July 20th she had her first catamenia for six years. Her skin was not peeling nor was her hair falling out. July 26th she looked and felt tired and her dose of thyroid was reduced to $1 \frac{1}{2}$ grains daily. On this dose she felt brighter and stronger. She could do her own housework without unusual fatigue and she was not sleepy in the day time. She continued thus, with a basal metabolism in the region of minus 13 per cent, until the end of October, when she began to feel drowsy most of the time and to mind the cold. Otherwise, she was well except for ataxia, which, however, occurred only when she left home. She reentered the hospital November 22nd. After rest in bed she felt brighter and stronger. It was decided that her ataxia, which was associated with absent 
knee jerks, was probably unrelated to her myxedema. There was no essential change in her basal metabolism.

November 28th, she was given $10 \mathrm{mgm}$. of thyroxin intravenously at 8 p.m. Desiccated thyroid, grains $1 \frac{1}{2}$ daily, was continued. During the night her head began to ache. Next morning her headache was gone, but she felt more nervous and restless. In the evening she vomited. On the 30th she felt exceedingly warm. Her skin was hot although not moist, and her temperature was $101.5^{\circ} \mathrm{F}$. She had a headache and was thirsty. She was not passing more urine. December 1st she had no headache, nausea or fever, but she felt weaker and more nervous. On the 2nd her nervousness had decreased. On the 3rd she felt "fine" and continued thus, except for a transient attack of aches and pains on December 15th. Her basal metabolism reached its pre-injection level of minus 13 per cent about December 21st. On the 31st she was discharged from the hospital, with a basal metabolism of minus 18 per cent. She felt much brighter and livelier than on admission and had no ataxia. One and one-half grains of thyroid was continued at home. On this dose she felt well until February 1928, when she had begun to be dopey and drowsy again. Thyroid was increased to 3 grains daily. On this dose her metabolism rose to normal, she became more nervous and tired more easily. Her appetite was poor. She had no palpitation. She reentered the hospital November 17th. There were no signs or symptoms of myxedema and her basal metabolic level was minus 6 per cent.

She was given $10 \mathrm{mgm}$. of thyroxin intravenously at 6 p.m., November $26 \mathrm{th}$. At about 10 o'clock that night a dull headache which she had had for several days, became much worse, and she became nauseated. Next morning there was some tenderness of the leg and arm muscles: this became more pronounced towards evening. She was very nervous, had a tremor, was unusually thirsty and perspired a great deal. That night she had severe pain about the umbilicus and vomited four times. On the 28th her nausea and headache were less marked, and her skin was not so warm. Her temperature was $100^{\circ} \mathrm{F}$. Her muscles were still sore. On the 29th she was much less nervous and she had no tremor or nausea. Muscle tenderness was much less marked. Her skin temperature was about normal. November 30th she had some palpitation and nausea in the morning, and she felt nervous and jumpy. In the afternoon her heart was quieter. Her skin felt warm and her leg muscles were still quite tender. She was drinking more water and passing more urine. December 1st, her appetite, which had been poor since injection, improved. On the 2 nd, muscle tenderness was confined to the legs, which were moderately tender. She had no cardiac symptoms. December 5th she was feeling well. The muscles of her right calf were still slightly tender. By the 7th muscle tenderness had completely disappeared. From then on, her progress was uneventful, except for a mild upper respiratory infection about December 17th. Her basal metabolism reached its pre-injection level of minus 6 per cent about December 19th. She was discharged on 3 grains of thyroid daily, on the 21st. March 11th, 1929, when last seen, she was well. 
There were no signs or symptoms of myxedema and her basal metabolism was plus 2 per cent.

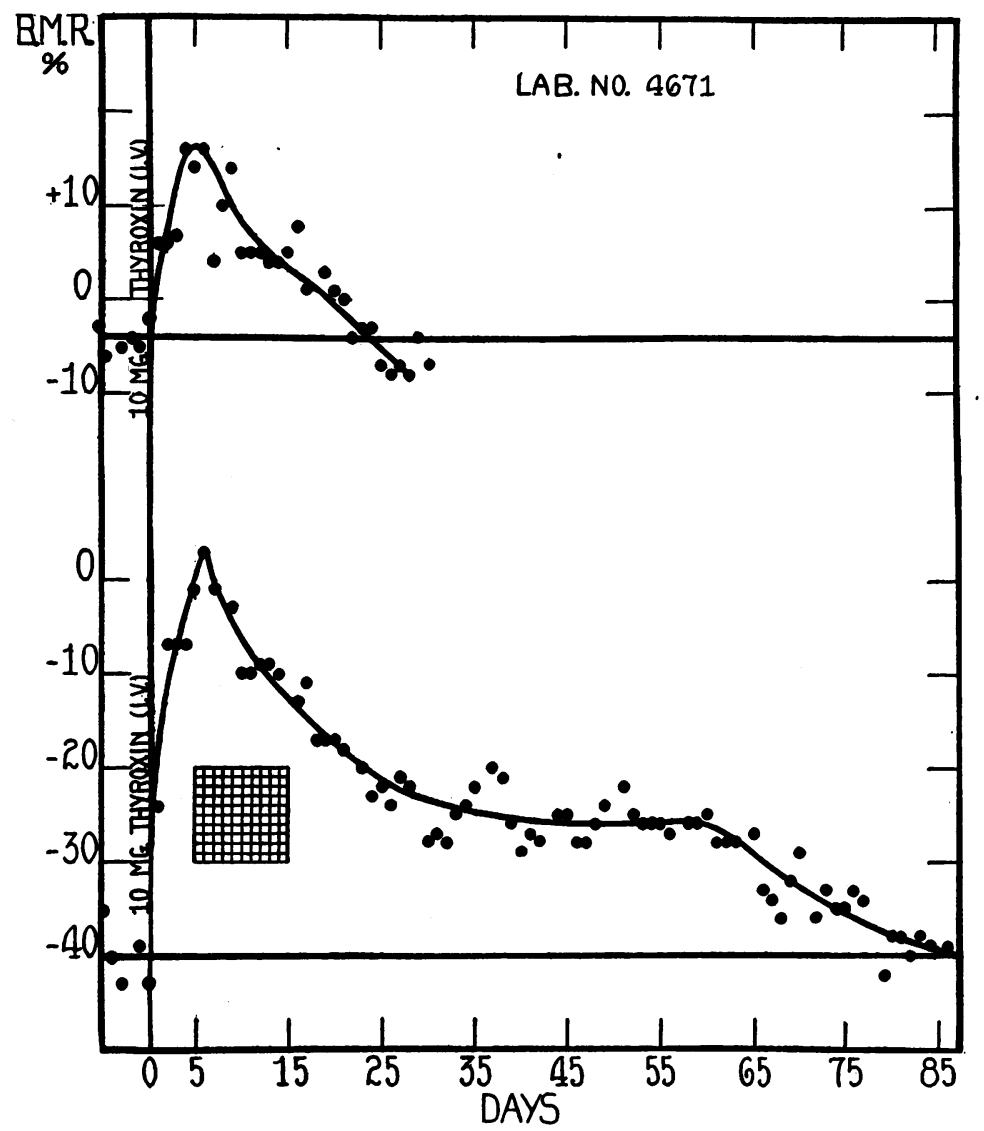

Fig. 3. Case 1. Showing in Detail the Marked Differences in the Magnitude and DURation of the Increase in Basal Metabolism Following the Intravenous InJection of 10 mgm. of Thyroxin, at Different Metabolic Levels (Minus 40 Per Cent and Minus 4 Per Cent)

Comparison of effect on basal metabolism of the intravenous injection of $10 \mathrm{mgm}$. of thyroxin when the patients were myxedematous and when they were normal

It may be noted from figures 3 and 4 that, when the patients were myxedematous, the increase in basal metabolism following the intra- 


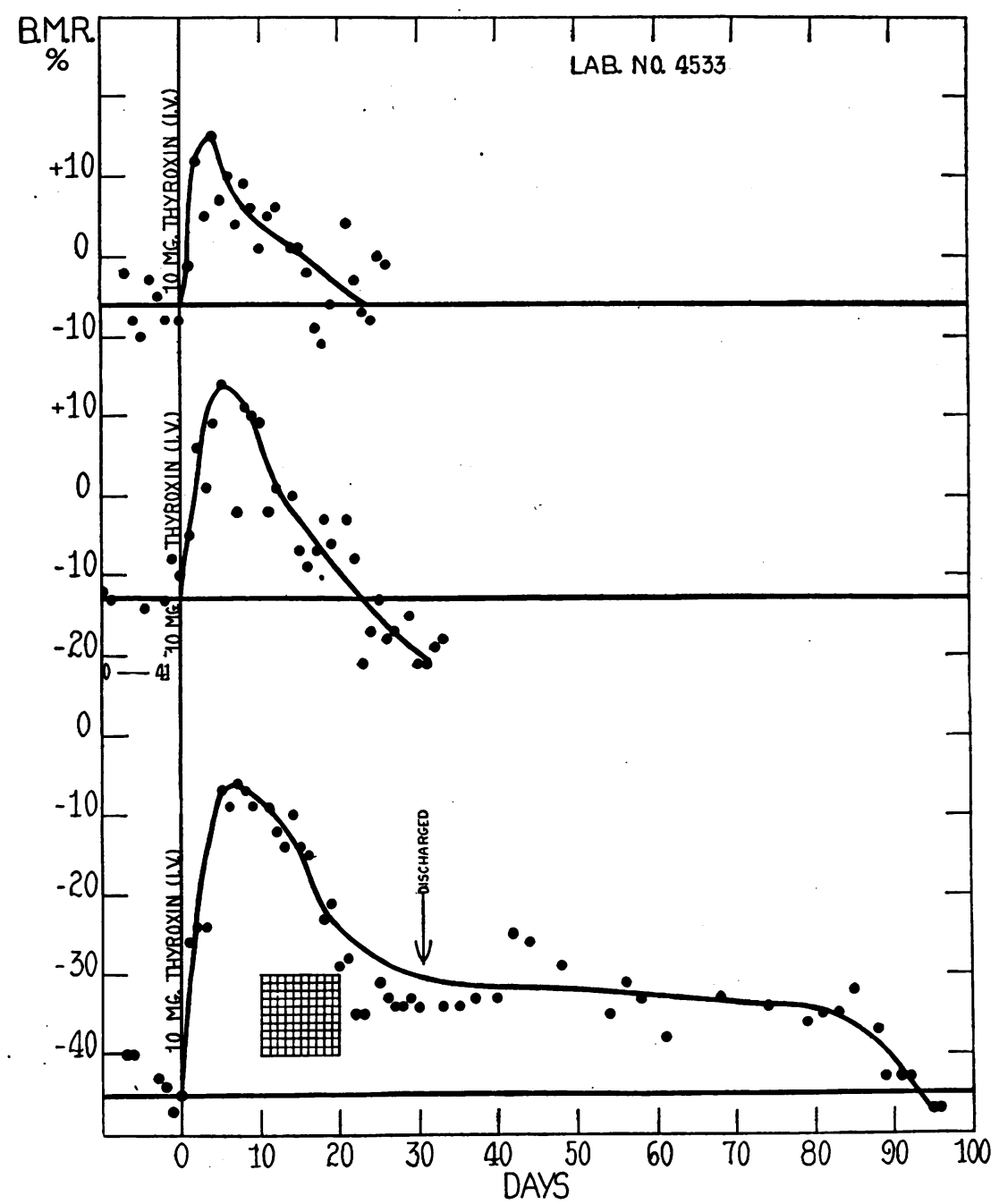

Fig. 4. Case 2. Also Showing in Detall the Marked Differences in the Magnitude and Duration of the Increase in Basal Metabolism Following the Intravenous InJection of 10 Mgm. of Thyroxin, at Different Metabolic Levels (Minus 45 Per Cent, Minus 13 Per Cent and Minus 6 Per CENT) 
venous injection of $10 \mathrm{mgm}$. of thyroxin was of much greater magnitude and of much longer duration than when the patients were normal. These differences are summarized in table 1.

The total excess heat produced by each injection of 10 milligrams of thyroxin was estimated as follows: '

The daily metabolic rates were plotted on graph paper ruled in small squares (sample insert in each figure), each small square representing a change of 1 per cent in the standard normal basal calories

TABLE 1

Summary of effect on basal metabolism produced by the intravenous injection of $10 \mathrm{mgm}$. of thyroxin at different metabolic levels in myxedema

\begin{tabular}{|c|c|c|c|c|c|c|c|c|c|c|}
\hline 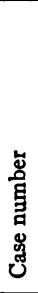 & 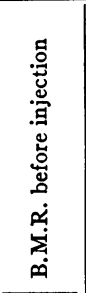 & 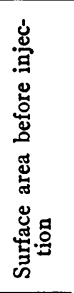 & 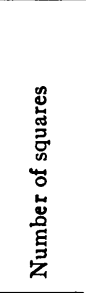 & 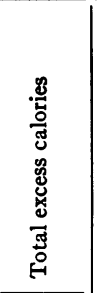 & 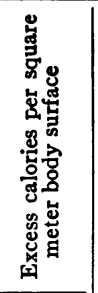 & 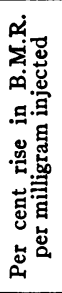 & 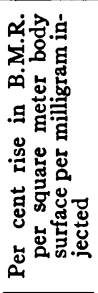 & 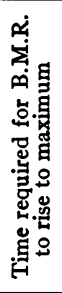 & 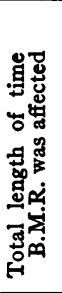 & 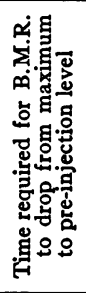 \\
\hline & per cent & $s q . m$. & & & & & & days & days & days \\
\hline 1 & -40 & 1.89 & 1,375 & 22,455 & 11,880 & 4.3 & 2.3 & 6 & 86 & 80 \\
\hline 1 & -4 & 1.74 & 221 & 3,320 & 1,910 & 2.0 & 1.2 & 4 & 24 & 18 \\
\hline \multirow{3}{*}{2} & -45 & 1.65 & 1,458 & 21,075 & 12,770 & 3.9 & 2.4 & 5 & 93 & 85 \\
\hline & -13 & 1.57 & 303 & 4,165 & 2,655 & 2.7 & 1.7 & 5 & 23 & 18 \\
\hline & -6 & 1.60 & 201 & 2,815 & 1,760 & 2.1 & 1.3 & 4 & 23 & 19 \\
\hline
\end{tabular}

per square meter per 24 hours. A curve was drawn through the points thus plotted, to denote the actual course of the metabolism. The base line was the level of the metabolism before the injection of thyroxin. The number of squares contained in the area bounded by the base line and the curve was counted. The difference in the number of squares in the graphs at different metabolic levels gives a fairly close estimate of the difference in the magnitude of the response at each level: but to bring each response to terms of total excess heat production, the normal basal metabolic rate (Aub-DuBois standards) in calories for 24 hours was multiplied by the number of squares and the result divided by one hundred. 
Example:

Case 1.

Basal metabolic rate before injection, minus 40 per cent.

Standard normal calories per square meter per hour $=36.0$.

Body surface before injection $=1.89$ square meters.

If metabolic rate were standard normal before injection, total basal calories for 24 hours would be $36.0 \times 24 \times 1.89$.

Number of squares in graph $=1375$.

Total excess calories produced by $10 \mathrm{mgm}$. of thyroxin $=\frac{36.0 \times 24 \times 1.89 \times 1375}{100}$ $=22,455$.

Total excess calories per square meter produced by $10 \mathrm{mgm}$. of thyroxin = $\frac{36.0 \times 24 \times 1375}{100}=11,880$.

The method used is rough, but is sufficiently accurate, considering the number of other variables which enter into the situation, to show the marked differences in reaction which occur at different levels of basal metabolism. ${ }^{3}$

When the patients were myxedematous with basal metabolic rates of minus 40 and minus 45 per cent, the total excess heat produced by the injection of $10 \mathrm{mgm}$. of thyroxin was $\frac{22,455}{3,320}=6.8$ times and $\frac{21,075}{2,815}=7.5$ times as great respectively as when they were normal with rates of minus 4 and minus 6 per cent.

It is of interest that the ascending portions of the curves occupied about the same length of time (4 to 6 days) at both the normal and the myxedematous levels, being possibly a little shorter at the normal level.

The rate of increase in heat production was greatest immediately following injection, particularly at the myxedematous level. Thus in case 1 it had risen 16 out of 43 points within 18 hours after injection and 33 points within 42 hours: it then remained at a level for another 48 hours before starting to rise to its maximum, which was reached 138 hours after injection. In case 2 it had risen 20 out of 39 points

${ }^{3}$ In each calculation the figure used for surface area is that of the patient just before injection. The ensuing changes in area are not taken into account, because the influence on final results is so slight. 
within 18 hours after injection, and then remained at about the same level for another 48 hours before starting to rise to its maximum, which was reached 114 hours after injection.

The descending portions of the curves occupied a much longer time when the injection was given at the myxedematous levels (80 to 85 days) than when it was given at the normal levels (18 to 19 days). At the normal levels, the initial part of the fall was perhaps a little steeper than the last part. The long plateau, at a level a little above the base line, which was an outstanding feature of the descending portion of the curve when the injection was given at a myxedematous level, was missing.

Comparison of effect on clinical condition of the intravenous injection of 10 mgm. of thyroxin when the patients were myxedematous and when they were normal

As the clinical histories show, there were two outstanding differences:

1. The symptoms attributable to intoxication, viz., vomiting, anorexia, fever, headache, palpitation, increased thirst, tremor and muscle tenderness, were all more marked when the patients were myxedematous than when they were normal.

2. The clinical improvement at the myxedematous level was striking: at the normal level, the only effect was a toxic one.

It is of interest that the degree of muscle tenderness and the increase in temperature following injection appear to vary directly with one another. Thus, in the first patient, there was only slight muscle tenderness even at the myxedematous level; and the temperature was only slightly elevated (fig. 5) at the myxedematous and not at all at the normal level. In the second patient, however, the muscle tenderness was very severe at the myxedematous level and the temperature was correspondingly high, viz., 104 degrees Fahrenheit (fig. 6): at the normal level both were less affected, but nevertheless were as marked as in the first patient at the myxedematous level. These observations suggest that the muscle tenderness and increase in body temperature following the injection of thyroxin, may be due to the same cause, i.e., destruction of tissue.

A striking feature was the rapidity with which the clinical reaction 
appeared following the injections. This was shown particularly when the injection was given at the myxedematous level. Thus, in case 1 ,

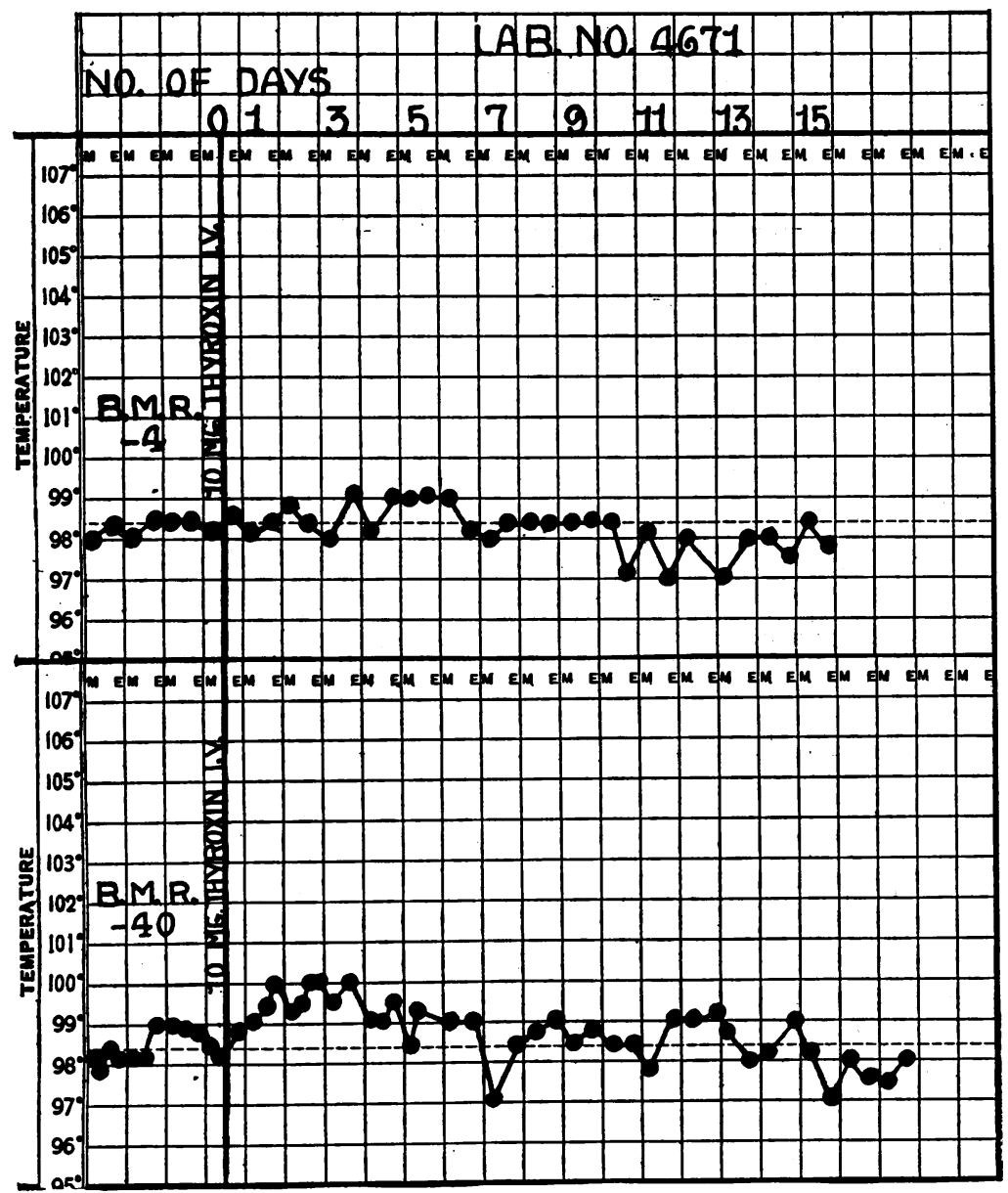

Fig. 5. Case 1. The Efrect on Body Temperature of the Intravenous InJection of 10 MgM. OF Thyroxin at Different Metabolic LeVels (MINUS 40 Per Cent and Minus 4 Per Cent)

as evidenced by increased pulse rate and temperature, the reaction had begun 3 hours after injection. In case 2, where the patientwas not followed closely immediately afterward, all that was noted was 


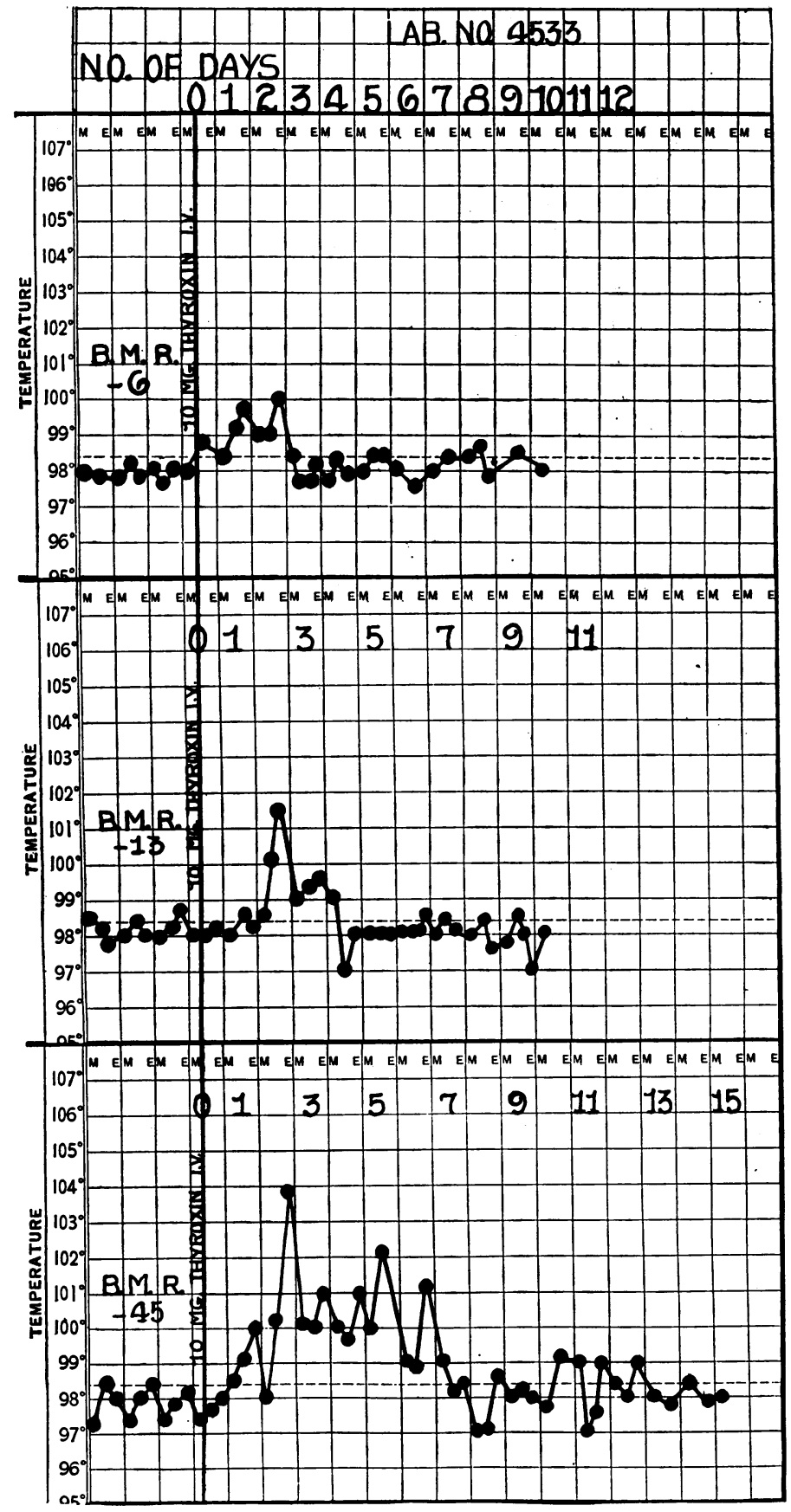

Fig. 6. Case 2. Also Showing the Effect on Body Temperature of the Intravenous Injection of 10 mgm. OF Thyroxin at Different Metabolic Levels (Minus 45 Per Cent, Minus 13 Per Cent and Minus 6 Per CENT) 
TABLE 2

Comparison of clinical condition of patients before the injection of $10 \mathrm{mgm}$. of thyroxin and after its effect on basal metabolism had worn off (myxedematous level)

\begin{tabular}{|c|c|c|c|c|}
\hline & \multicolumn{2}{|c|}{ Case 1} & \multicolumn{2}{|c|}{ Case 2} \\
\hline & $\begin{array}{l}\text { Before injection of } \\
10 \text { mgm. thyroxin. } \\
\text { B.M.R. }-40 \text { per } \\
\text { cent }\end{array}$ & $\begin{array}{l}86 \text { days after injec- } \\
\text { tion of } 10 \mathrm{mgm} \text {. } \\
\text { thyroxin. B.M.R. } \\
-40 \text { per cent }\end{array}$ & $\begin{array}{l}\text { Before injection of } \\
10 \text { mgm. thyroxin. } \\
\text { B.M.R. }-45 \text { per } \\
\text { cent }\end{array}$ & $\begin{array}{l}93 \text { days after injec- } \\
\text { tion of } 10 \text { mgm. } \\
\text { thyroxin. B.M.R. } \\
-45 \text { per cent }\end{array}$ \\
\hline Weight. . & $78 \mathrm{kgm}$. & 72 kgm. & $63 \mathrm{kgm}$. & $58 \mathrm{kgm}$. \\
\hline Pulse...... & 68 & 62 & 62 & \\
\hline Edema. . & $\begin{array}{l}\text { Face, legs, } \\
\text { hands and } \\
\text { abdomen } \\
\text { swollen }\end{array}$ & $\begin{array}{l}\text { Eyelids swol- } \\
\text { len. No no- } \\
\text { ticeable } \\
\text { edema else- } \\
\text { where. Skin } \\
\text { on hands } \\
\text { loose }\end{array}$ & $\begin{array}{l}\text { Face, legs, } \\
\text { hands and } \\
\text { abdomen } \\
\text { swollen }\end{array}$ & $\begin{array}{l}\text { Eyelids slight- } \\
\text { ly swollen. } \\
\text { No edema of } \\
\text { legs or hands. } \\
\text { Abdomen } \\
\text { slightly } \\
\text { swollen }\end{array}$ \\
\hline Skin. . & $\begin{array}{l}\text { Very dry and } \\
\text { scaly. } \\
\text { Marked pig- } \\
\text { mentation of } \\
\text { face and } \\
\text { arms }\end{array}$ & $\begin{array}{l}\text { Moderately } \\
\text { dry. Pig- } \\
\text { mentation } \\
\text { markedly } \\
\text { faded }\end{array}$ & $\begin{array}{l}\text { Very dry and } \\
\text { scaly }\end{array}$ & Slightly dry \\
\hline Hair.... & $\begin{array}{l}\text { Very dry and } \\
\text { brittle }\end{array}$ & Not dry & $\begin{array}{l}\text { Very dry and } \\
\text { coarse }\end{array}$ & Not dry \\
\hline Tongue.. & $\begin{array}{l}\text { Large and } \\
\text { thick }\end{array}$ & Slightly thick & $\begin{array}{l}\text { Large and } \\
\text { thick }\end{array}$ & Normal \\
\hline Voice....... & Hoarse & $\begin{array}{l}\text { Slightly } \\
\text { hoarse }\end{array}$ & Hoarse & $\begin{array}{l}\text { Slightly } \\
\text { hoarse }\end{array}$ \\
\hline Gait.... & $\begin{array}{l}\text { Markedly } \\
\text { unsteady }\end{array}$ & $\begin{array}{l}\text { Slightly } \\
\text { unsteady }\end{array}$ & $\begin{array}{l}\text { Markedly } \\
\text { ataxic }\end{array}$ & Spells of ataxia \\
\hline Slowness: & & & & \\
\hline Of movement. & $++t+$ & + & $+t+$ & + \\
\hline Of speech...... & +++ & + & ++ & + \\
\hline Of thought.... & ++ & + & $++t$ & + \\
\hline Hearing. ........ & Poor & Good & -- & -- \\
\hline Memory......... & Very poor & Fair & Very poor & Fair \\
\hline Sensitivity to cold. & $++t$ & $\mathbf{0}$ & $+t+t$ & ++ \\
\hline $\begin{array}{l}\text { Numbness of } \\
\text { extremities . . . . }\end{array}$ & ++ & + & -- & -- \\
\hline Drowsiness...... & $+t+t$ & ++ & ++++ & ++ \\
\hline Weakness... & $++t$ & + & $+t+$ & + \\
\hline Headaches... & 0 & & + & + \\
\hline Appetite.... & Poor & Fair & Poor & Rather poor \\
\hline Nausea.......... & 0 & $\mathbf{0}$ & + & + \\
\hline Constipation..... & +++ & + & +++ & ++ \\
\hline
\end{tabular}


polyuria 9 hours after injection. The day after injection there was a noticeable diminution in the edema of the eyelids in both instances: the patients looked brighter and moved a little more quickly. The second patient, after the second injection (basal metabolic rate before injection minus 13 per cent) developed a headache in about 4 to 6 hours, and after the third injection (basal metabolic rate before injection minus 6 per cent), a headache which had been present for several days, became worse 4 hours later and she became nauseated.

The height of the intoxication was reached on the second day following all injections except the second one in the first patient. In this instance, it was reached on the fourth day after injection. In both patients at the myxedematous level, all the symptoms of intoxication had begun to abate after the fifth day. Following the second injection in the first patient, the peak of the reaction was over in six days: and following the last two injections into the second patient, the symptoms attributable to intoxication had practically disappeared by the fifth day.

When the patients were myxedematous, the clinical benefit of the injection of $10 \mathrm{mgm}$. of thyroxin was not at its height until three weeks after injection; and at this time the weight was still falling although the basal metabolism had dropped to minus 20 per cent in case 1 and minus 28 per cent in case 2 . In the first patient, whose hospital routine was not disturbed, this benefit continued unabated for three more weeks, by. which time she had lost a little more weight and her basal metabolism had fallen to minus 28 per cent. In both patients the reversion to myxedema was very gradual and by no means complete. When their basal metabolic rates had returned to their pre-injection levels of minus 40 and minus 45 per cent respectively, both patients showed very few manifestations of thyroid deficiency and moreover weighed 6 and 5 kilograms less respectively than before injection, although at these same levels of metabolism they had previously been classical cases of myxedema. Table 2 illustrates this point.

\section{DISCUSSION}

\section{A. Differences in excess heat production}

That the decrease in the magnitude of the reaction to the intravenous injection of $10 \mathrm{mgm}$. of thyroxin at a normal level of basal 
metabolism as compared with a myxedematous level of metabolism, is not due to the establishment of a tolerance to thyroid substance, is upheld by the following considerations:

1. We have never encountered a case of myxedema, in which a dose of desiccated thyroid which was definitely established by administration for a long enough period of time to be sufficient for maintenance, had to be increased later because of the development of a tolerance to the substance.

2. The response of normal and obese individuals to desiccated thyroid by mouth (1) (3) (4) (5) or to thyroxin given intravenously (2) (6) is less than that of patients with myxedema.

A more reasonable explanation of the decrease observed, is that at the myxedematous level, the thyroxin is supplying a marked, perhaps complete deficiency of thyroid gland secretion, whereas at a normal level, thyroxin is being given in excess. The body would be expected to deal with these different situations in a different manner, in the latter instance bringing into play some mechanism which would tend to keep conditions constant.

By injecting the thyroxin intravenously, it can be made certain that it is completely absorbed by the blood stream: but the amount, time and method of its absorption by other tissues and its excretion from the body, under different circumstances, are practically unknown. Kendall (7) states that within fifty hours after 200 milligrams were injected into the saphenous vein of a dog, 43 per cent of the total iodine contained in the thyroxin was excreted in the bile and 13 per cent in the urine. In this case the thyroxin was given in great excess so that these figures probably do not represent the per cent of a 10 $\mathrm{mgm}$. dose that is excreted unused when given to a patient with myxedema.

It is reasonable to assume that under normal conditions, when the rate of cell metabolism is more rapid than in the myxedematous condition, the excretion of thyroxin may also be more rapid. This may be at least one element in the mechanism which, at a normal level of metabolism, guards against the effects of excess dosage of thyroxin.

Incidentally, a curve denoting the effect on basal metabolism of an intravenous dose of thyroxin represents only the effect of whatever fraction of that dose is not eliminated from the body unused at one 
time or another during the course of the observations. One would expect this fraction to vary under different circumstances.

Plummer and Boothby (8) state that in myxedema, 1 milligram of thyroxin injected intravenously raised the basal metabolism an average of 2.8 per cent. Their table shows that they divided their myxedematous patients into groups according to the metabolism, which ranged from below minus 35 per cent to above minus 14 per cent. The lower the metabolism, the larger the dose of thyroxin administered. Their results ranged irregularly from 1.6 to 3.5 per cent increase in metabolism per milligram of thyroxin injected. In the groups with metabolic rates "above minus 14 per cent," "minus 15 to minus 19 per cent" and "minus 35 per cent and below" (the only ones in which significantly different doses were given at the same metabolic level), the results suggest that the greater the dose the less the increase in metabolism per milligram of thyroxin injected. That the size of the dose may affect such results is indicated by Kendall's (9) observation that the injection of one enormous dose $(200 \mathrm{mgm}$.) into a dog had no more clinical effect than a single small dose. While 2.8 per cent rise per milligram is the proper average for Plummer and Boothby's observations throughout their metabolic range, and may be for such observations in general, it should be understood that the variations allowed for by this figure are within rather wide limits. Our findings indicate that for a $10 \mathrm{mgm}$. dose, the variation may range from a rise of 4.3 per cent per milligram to a rise of only 2 per cent per milligram, depending upon the initial level of the basal metabolism within the range of minus 45 to minus 4 per cent.

Boothby, Sandiford, Sandiford and Baldes (10) have attempted to reduce the relation between the size of the dose and the excess heat production to mathematical terms. On the basis of their interesting. data most of which are charted in another article (2), and which were made on one myxedematous patient, they tentatively estimate that the continued administration of an average intravenous dose of 0.25 mgm. of thyroxin daily raised the heat production approximately 525 calories above the myxedematous basal level of 1100 calories; an average dose of $1 \mathrm{mgm}$. daily raised it approximately 825 calories and $2 \mathrm{mgm}$. daily, approximately 1020 calories. As this relation between 
dose and extra heat is a straight line on logarithmic paper, they suggest the following equation to represent it:

$$
\log H-n \log T=K
$$

where $H$ represents the excess calories and $T$ the daily dose of thyroxin necessary to maintain $H$.

As the authors evidently realize however, judging by the fact that they offer it as only a preliminary suggestion, there are possibilities for error in this generalization. The most serious criticism of their formula is that the actual doses were not $0.25,1$ and $2 \mathrm{mgm}$. daily, but averages of different doses given at longer intervals, viz., 1 to 14 days. The results of such a program of medication may differ from the results that would be obtained from actually giving $0.25,1$ and $2 \mathrm{mgm}$. daily, on account of possible differences in the rate of excretion of thyroxin. Moreover, the per cent of thyroxin excreted unused when the dose is $2 \mathrm{mgm}$. daily may be different from that excreted unused when the dose is smaller. Another consideration is that there may be a different relationship between excess heat and dose at levels of basal metabolism below standard normal, from that which obtains above normal.

\section{B. Differences in length of descending portions of the curves}

Plummer (6) makes the general statement that, in a thyroidless individual, the effect on basal metabolism of an intravenous injection of thyroxin-sufficient to bring the metabolism to normal-wears off in 5 to 7 weeks. In another article (11), he states that the effect of 14 mgm. may not have completely worn off in 8 weeks. Boothby, Sandiford, Sandiford and Slosse (2) report two curves on a myxedematous patient. The first represents the rate of decrease of the metabolism which had been raised by 3.9 grams of desiccated thyroid by mouth, and occupies a minimum of 45 days. The other represents the rate of disappearance of the effect on metabolism of an average intravenous dose of $1 \mathrm{mgm}$. of thyroxin daily for about a month, and occupies a theoretical minimum of about 55 days. The curve is not plotted on actual data in the last half of its course. In another article (12) Boothby and Sandiford state that the time required for the heat production to decrease from the maximum to one- 
tenth of this amount, is found by extrapolation to be usually between 30 and 70 days for thyroxin. W. A. Plummer (13) states that the effect of an intravenous injection of thyroxin on metabolism in myxedema sometimes lasts for 10 weeks. Baumann and Hunt (14) on the basis of their experiments on "the specific dynamic action of glucose" following complete thyroidectomy in rabbits, concluded that it took about 65 days for the thyroid secretion in the tissues to become exhausted. Magnus Levy (15) found in his myxedematous patient that it took about 80 days for the effect of thyroid feeding on basal metabolism to wear off.

As may be seen from figures 3 and 4, the level of the metabolism at the time of injection of thyroxin has a very important bearing on the time occupied by the decrease in basal metabolism, and consequently upon the total amount of excess heat produced. This may explain some of the differences noted by various observers in the duration of the descending portion of the curve.

\section{Possible significance of the lag of clinical effects behind basal metabo- lism after injection of thyroxin when the patients were myxedematous}

The marked lag in disappearance and reappearance of clinical signs and symptoms of myxedema behind the rise and fall in basal metabolism illustrates the striking slowness with which the chemical changes in tissues that are characteristic of myxedema occur. In terms of basal metabolic rate, the effect of the injection of $10 \mathrm{mgm}$. of thyroxin in myxedema is completed in 90 days, but in terms of general well-being, the effect lasts for some time longerprobably several months. If the latter effect be due to some residual thyroxin in the tissues, then the rate of destruction of thyroxin has never been even approximately determined. If it is merely an expression of some mechanism which thyroxin has set into play and which is acting long after the thyroxin itself has become exhausted, then there is no guarantee that at least part or possibly all of the descending portion of the basal metabolism curve is not of the same nature. Possibilities such as these make one hesitate to apply formulae to the descending parts of the curves of metabolism and 
to use the results to calculate the amount of thyroxin in the body.4 Even if there were sufficient data, well controlled as to dosage and level of metabolism at the time of injection, one would be at a loss to know at what point all the thyroxin actually disappeared from the reaction.

Boothby, Sandiford, Sandiford and Baldes (10) state that the data of the descending portions of their three curves on one myxedematous patient lie within the experimental error of an exponential curve of the following formula:

$$
H+H^{\prime}=1660 \times 10^{-0.024 t}+1150
$$

where $H=$ excess heat calories due to thyroxin and 1660 is an arbitrary value for zero day; $10^{-0.024}$ is the exponential constant, $t$ the number of days following the zero day and $H^{\prime}$ is 1150 , the heat production of the myxedematous subject before the administration of thyroxin. The excess heat production when plotted on semi-logarithmic paper against time fell on a straight line and could be expressed by the above formula. Therefore, they tentatively assumed that this excess heat was dependent on some function of the concentration of thyroxin in the body. They further state that "if we assume that the excess heat is directly proportional to the concentration of thyroxin in the body then the disappearance of thyroxin from the body obeys the same law as the excess heat production and the rôle of the thyroxin is identical with that of a specific catalyst and follows the law of monomolecular reactions."

Rabinowitch (16) points out that while the descending portion of the curve possibly may be explained on such a basis, the ascending portion cannot be. "Since we are dealing with a reaction which increases in magnitude for a number of days after the administration of a single dose of the drug, it is obvious that the concentration of that

${ }^{4}$ Inasmuch as the rate at which thyroxin is used and the magnitude of its effect appear to depend upon the level of the basal metabolism before injection and the size of the dose given; inasmuch as the basal metabolism does not necessarily record the concentration of thyroxin in the tissues; and inasmuch as the rate and time at which it disappears from the reaction when its administration is stopped cannot be determined at present, we find it difficult to understand how Plummer (11) calculated that there are about $14 \mathrm{mgm}$. of thyroxin in the body of a normal man. His method of making this calculation is not recorded. 
drug in the tissues is not the only governing factor." He suggests that we are dealing with a form of growth in which the rate of increment is at any particular instant proportional to the magnitude of that which is increasing. Thus the successive rates of heat production at the end of a series of intervals would form the terms of a geometrical progression, according to the formula

$$
Q_{t}=Q_{0} e^{k t} \text { or } k=\frac{2.302}{t} \cdot \log _{10} \cdot \frac{Q_{o}+X_{t}}{Q_{0}}
$$

where $Q_{o}=$ the original quantity, $k=$ constant, $Q_{t}=$ the amount to which $Q_{o}$ has grown in time $t$ and $X_{t}=$ the increment during time $t$. "If the law is applicable, it should be possible to predict the heat production at the end of any period of observation, once the constant of increment is known." When a constant value for $k$ was used throughout the period of increment, the calculated results agreed reasonably well with the observed results. If values for $k$ were calculated at different intervals, however, a marked inconstancy was noted. $\mathrm{He}$ found a similar variation in the value for $k$ in the descending portion of one of the curves of Boothby and Rowntree (17). He therefore concluded that "we are either not dealing with a reaction that follows the unimolecular law, or, as in the case of ferments, the fall in $k$ may be attributed to destruction of the catalyst. If, however, the latter explanation is accepted, it is difficult to reconcile the increase in the rate of heat production which follows with the view that the heat production is a direct function of the concentration of thyroxin in the tissues." He suggests the possibility that, during the reaction, certain compounds are formed which are catalytic and may account for the prolonged effect following the administration of thyroxin.

The slope of the descending portions of our curves would appear to agree with the contention of Rabinowitch that the reaction is not a monomolecular one: and we are of the opinion that it is at present hopeless to give a satisfactory theoretical and mathematical treatment of so complex a biological phenomenon.

\section{Bearing of our results on the treatment of myxedema}

We have frequently noticed that after the basal metabolism has been raised to a normal level in patients with myxedema, it is often possible, 
by increasing slightly the oral dose of thyroid ( $\frac{1}{2}$ to $1 \frac{1}{2}$ grains of Armour's thyroid daily), to produce unpleasant clinical symptoms without much increase in basal metabolism. For instance, in our first patient, 3 grains of desiccated thyroid were continued daily for nearly five months after the second injection of thyroxin. As shown in figure 1 , after the effects of the injection had worn off, although the basal metabolism remained approximately normal (plus 2 to plus 4 per cent, with the exception of one determination of plus 13 per cent shortly after she went home), her weight dropped steadily. She developed some palpitation and precordial pain, was nervous, fatigued easily, perspired more than usual and looked worn out. On reducing the dose of desiccated thyroid to $1 \frac{1}{2}$ grains daily, her metabolism was still within normal limits (minus 9 to minus 2 per cent), and she gained weight. Her symptoms of thyroid intoxication disappeared and there was no evidence of myxedema.

Our results with thyroxin are in harmony with this observation. The frequent lack of effect on metabolism of a slight excess of desiccated thyroid when given at a normal level of metabolism is similar to the very moderate effect produced at this level by a large excess (10 mgm.) of thyroxin.

Inasmuch as a small excess of thyroid is not necessarily reflected in the level of the basal metabolism, the latter is not the only factor to be considered in gauging the proper maintenance dose for a patient with myxedema. The determination of the dose of desiccated thyroid must be in part based upon a careful clinical study of the patient.

\section{SUMMARY}

In two patients with myxedema, the intravenous injection of 10 mgm. of thyroxin produced more marked effects at a low level of metabolism (minus 40 and minus 45 per cent) than at a normal level of metabolism (minus 4 and minus 6 per cent respectively). This is shown by the following facts:

1. The total excess heat produced was about seven times as great viz., 22,455 calories vs. 3,320 calories in the first case; and 21,075 vs. 2,815 calories in the second case.

2. The per cent rise in basal metabolism per milligram of thyroxin 
injected was about twice as much, viz., 4 per cent per milligram vs. 2 per cent per milligram.

3. The length of time occupied by the descending portion of the metabolism curve was about four times greater, viz., 80 to 85 days vs. 18 to 19 days.

4. The unpleasant clinical effects, including elevation of temperature, were more marked.

5. The beneficial clinical effects were marked at the myxedematous level. At the normal level, the only effect was a toxic one.

The appearance and disappearance of the clinical improvement lagged considerably behind the rise and fall in basal metabolism when the injection was given at the myxedematous level.

The time occupied by the ascending portions of the curves varied from 4 to 6 days, and appeared to be approximately the same at the normal level as at the myxedematous level.

The slope of the descending portions of our basal metabolism curves following the injections at the lowest levels of metabolism, does not support the hypothesis of Boothby et al that the reaction is a monomolecular one.

\section{CONCLUSIONS}

The level of the basal metabolic rate at the time of the intravenous injection of a given dose of thyroxin into a myxedematous patient, has a marked influence upon the amount of excess heat produced and upon the intensity of both the unpleasant and the beneficial clinical effects.

The multiplicity of unmeasured factors involved in the reaction produced by thyroxin makes it impossible at present to reduce the effect to accurate mathematical terms. The most important of these factors appear to be the amount of injected thyroxin that is effective, the nature of the chemical changes produced by thyroxin, and the time and rate at which thyroxin disappears from the reaction - a factor which may not be accurately gauged by changes in the basal metabolism.

The clinical condition of the patient is just as important as the basal metabolic rate in determining the proper maintenance dose of thyroid for a patient with myxedema. 


\section{BIBLIOGRAPHY}

1. Thompson, W. O., J. Clin. Invest., 1926, ii, 477. Studies in Blood Volume. I. The Blood Volume in Myxedema, with a Comparison of Plasma Volume Changes in Myxedema and Cardiac Edema.

2. Boothby, W. M., Sandiford, I., Sandiford, K., and Slosse, J., Trans. Assoc. Am. Phys., 1925, xl, 195. The Effect of Thyroxin on the Respiratory and Nitrogenous Metabolism of Normal and Myxedematous Subjects. I. A Method of Studying the Reserve or Deposit Protein with a Preliminary Report of the Results Obtained.

3. Magnus-Levy, A., Ztschr. f. klin. Med., 1897, xxxiii, 269. Untersuchungen zur Schilddrüsenfrage. Gas- und Stoffwechseluntersuchungen bei Schilddrüsenfütterung, Myxödem, Morbus Basedowii und Fettleibigkeit.

4. Thiele, O., and Nehring, O., Ztschr. f. klin. Med., 1896, xxx, 41. Untersuchungen des respiratorischen Gaswechsels, unter dem Einflusse von Thyreoideapräparaten und bei anämischen Zuständen des Menschen.

5. Jaquet, A., and Svenson, N., Ztschr. f. klin. Med., 1900, xli, 375. Zur Kenntniss des Stoffwechsels fettsüchtiger Individuen.

6. Plummer, H. S., J. Am. Med. Assoc., 1921, lxxvii, 243. Interrelationship of Function of the Thyroid Gland and of its Active Agent, Thyroxin, in the Tissues of the Body.

7. Kendall, E. C., Endocrinology, 1919, iii, 156. The Physiologic Action of Thyroxin.

8. Plummer, H. S., and Boothby, W. M., Am. J. Physiol., 1921, lv, 295. Specific Dynamic Action of Thyroxin.

9. Kendall, E. C., Ann. Clin. Med., 1922-23, i, 256. The Chemistry and the Pharmacologic Action of Thyroxin.

10. Boothby, W. M., Sandiford, I., Sandiford, K., and Baldes, E. J., Abstr. of Commun. to the XIIth Internat. Physiol. Congress held at Stockholm, Aug. 3-6, 1926. Skandinav. Archiv. 1926, xlix, 99. Metabolism Studies Showing the Effect of Desiccated Thyroid and Thyroxin on a Patient with Myxedema.

11. Plummer, H. S., Oxford Medicine, Vol. iii, part ii, p. 839. Functions of the Normal and Abnormal Thyroid Gland.

12. Boothby, W. M., and Sandiford, I., J. Biol. Chem., 1924, lix, p. xl. A quantitative Estimate of the Catalytic Power of Adrenalin and Thyroxin as Calorigenic Agents and the Relative Rate of their Destruction.

13. Plummer, W. A., Ann. Clin. Med., 1923, i, 259. Clinical Features of Thyroid Disease.

14. Baumann, E. J., and Hunt, L., J. Biol. Chem. 1925, Ixiv, 709. On the Relation of Thyroid Secretion to Specific Dynamic Action.

15. Magnus-Levy, A., Ztschr. f. klin. Med. 1904, lii, 201. Ueber Myxödem.

16. Rabinowitch, I. M., J. Biol. Chem. 1924-25, lxii, 245. On the Action of Thyroxin.

17. Boothby, W. M., and Rowntree, L. G., J. Pharm. and Exper. Therap., 192324, xxii, 99. Drugs and Basal Metabolism. 